\title{
Strategies to Improve Teaching Effectiveness of Beginning Teachers in a School Setting
}

Ige Akindele Matthew: Director of School Services, Ondo State Ministry of Education, Science and Technology, Nigeria.

\begin{abstract}
That teachers are important in a school setting, cannot be overemphasized. A teacher however has to be equipped with knowledge and skills necessary for effective teaching of his/her pupils/students. Apart from the knowledge already acquired in educational institution(s), a teacher has to garner enough experience, to be effective in teaching. A beginning teacher possesses less teaching experience, compared to an old teacher. He/she needs adequate attention in school, to achieve his/her objectives, and most importantly, the school objectives, as well as effective teaching of pupils/students. In this paper, the strategies that can be adopted by school administrator, to improve the teaching of such teachers, such as: orientation, mentoring, exposure to workshops, conferences and seminars, among others, are examined.
\end{abstract}

Key words: Strategy, Improve, Teaching, Effectiveness, Teacher, Beginning teacher, School.

Accademia
International Journal of Educational
Studies
Vol. 2, No.4, pp. $261-268$
2019
DOI: $10.53935 / 2641-533 x$. v2i4.129
Funding: This study received no specific
financial support.
Article History:
Received: 16 August 2019
Revised: 26 September 2019
Accepted: 20 November 2019
Published: 19 December 2019
○ 2019 by the authors; licensee Academic
Publishing Group

Publishing Group

\section{Introduction}

There are many expectations from a teacher in a school setting. A teacher has to discharge $\backslash$ his/her duties conscientiously, such as the teaching of assigned subject(s), assessment of pupils/students; and participation in other school activities, such as the maintenance of discipline of pupils/students, just to mention a few. A major challenge of schools' administrators these days is how to manage the beginning teachers who are novices, inexperienced in teaching. A beginning teacher is a kind of teacher who is not accustomed to school programmes but only equipped with knowledge from tertiary institution(s). Even though he/she has the theoretical knowledge, these are yet to be demonstrated in classroom. Leaving such teachers unattended to by schools administrators could have grave consequences. For example, their inadequate experience could result to poor teaching and eventually, poor academic performance of the pupils/students, as well as high attrition of pupils/students from teaching due to frustration.

Unfortunately, it has been reported (National Centre for Education Statistics, 2010) that many talented and creative teachers, find teaching unrewarding and difficult while nearly $50 \%$ of newly hired teachers leave the job within five years Studies in Australia (Goddard \& Goddard, 2006; O'Brien \& Goddard, 2006) also revealed the high attrition rate for early-career teachers, at great cost to government. The dropout rate was highest among teachers in hard-to-staff, urban schools, which have the most difficulty both in attracting and retaining fully certified teachers (Ingersoll, 2001). Researches by Harris, Jenz, and Baldwin (2005) and Rhodes, Nevill, and Allan (2004) also found that beginning teachers entering teaching profession as a second career pathway, envisaged a short term career, spanning 5 to 8 years in teaching. It is imperative that the high rate at which teachers leave teaching be curtailed in view of the vacuum it will create in teaching-learning process. 


\section{Effective Teaching in Context}

According to Oxford Advanced Learners' Dictionary, effectiveness means: 'to produce successful result'. Effective teaching can thus be described as the ability of teaching to produce the desired results. The desired results could however be viewed from the perspective of achievement of lesson objectives, positive change in behaviour of pupils/students at the end of a lesson, or contribution to pupils/students' success. Afe (2003), however sees effective teaching as characterized by exhibition of intellectual, social, and emotional stability, love for children and positive disposition towards the teaching profession, as well as the ability to inspire good qualities in pupils/students. It is also the ability of instruction to inspire pupils/students of different abilities while incorporating instructional objectives and assessing the effective learning mode of pupils/students (Vogt, 1984); a manifestation of knowledge of content, skills in lesson presentation and creating desirable atmosphere for learning (Evans, 2006); and the achievement of all or most of the learning objectives and reduction of differences in cognitive levels among the pupils/students (Akpan, 1996). Notwithstanding the varied opinions on what effective teaching is, it can be further described as a kind of teaching that conforms to teaching norms, most importantly, achieves the stated objectives.

\section{Problems of Beginning Teachers in a School}

It is not a gainsaying that a beginning teacher faces challenges within and outside classroom. $\mathrm{He} / \mathrm{she}$ is a stranger in school who is not accustomed to policies and programmes of the school (Taneri, 2004), attitudes and ways of life of other teachers, as well as the pupils/students (Lundeen, 2004; Yalcnkaya, 2002). He/she thus needs much time to study and understand the situation in the new environment (i.e. school) and get accustomed to it.

$\mathrm{He} / \mathrm{she}$ cannot enforce discipline among pupils/students because of the fear of disobedience or rudeness by pupils/students (Aitken \& Harford, 2011), have difficulties in classroom management (Abdurrahman, 2016; Achistein \& Barret, 2004; Lundeen, 2004; Melnick \& Meister, 2008; Yalcnkaya, 2002). Also, pupils/students find it easy to disrespect a beginning teacher unlike an old teacher in a school. They are often isolated in school (Abdurrahman, 2016; Fry, 2007; Hover \& Yeager, 2004), have poor understanding of what is expected of them; are often given workload and extra assignments unprepared for; are not given supplies, materials or equipment to work (Matthews, 2011), and lack the support or help from the experienced teachers or supervisors (Veerman, 1984). Also, they have problem in designing the curriculum and implementing it in given time (Dunn, 2002), cited in Cantu Tijerina and Martinez Sanchez (2006), and in using specific techniques and addressing the needs of each student as an individual (Achistein \& Barret, 2004; Lundeen, 2004; Yalcnkaya, 2002).

In addition, they are often confronted by stringent government and school policies which are difficult for them to cope with. Although they possess theoretical knowledge in teaching, applying these might be a herculean task. Achievement of effective teaching by a beginning teacher may thus be a mirage (Robinstein, 2010). The old teachers perceive beginning teachers as those with fresh blood and high energy level, thus making schools administrators to often allocate more teaching workload and assignment for them. In addition, such teachers often find it difficult to keep and manage records appropriately because of inexperience.

\section{Strategies to Assist Beginning Teachers Achieve Effective Teaching}

Every profession has ways of training members to become experts/professionals. A newly graduated Doctor cannot be assigned a patient without acquiring the requisite experience even though he/she may have outstanding results from tertiary institution attended. A Law graduate also needs to serve as apprentice under an experienced lawyer for a particular period, to garner requisite experience necessary to defend a client or handle case (s) in court. In teaching, only the pre-qualification training (i.e. Teaching Practice) serves as avenue for training teachers towards effective teaching in school. The absence of post-qualification training or general post qualification induction for teachers in some countries, gives room for teachers to show a lot of weaknesses when employed in school. A beginning teacher cannot become an expert in a day or month. He/she needs much time on the job to become an

Vol. 2, No.4, pp. 261-268

2019

DOI: 10.53935/2641-533x.v2i4.129

financial support.

Article History:
Received: 16 August 2019

Revised: 26 September 2019

Accepted: 20 November 2019

Published: 19 December 2019

(C) 2019 by the authors; licensee Academic

Publishing Group expert or experienced. 


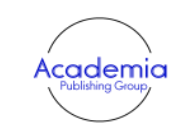

International Journal of Educational Studies

Vol. 2, No.4, pp. 261-268

2019

DOI: $10.53935 / 2641-533 x . v 2 i 4.129$

Funding: This study received no specific

financial support.

Article History:

Received: 16 August 2019

Revised: 26 September 2019

Accepted: 20 November 2019

Published: 19 December 2019

(C) 2019 by the authors; licensee Academic Publishing Group
Several approaches can be adopted by schools administrators to ensure that the beginning teachers achieve effective teaching, such as:

Orientation: A new employee needs to be accustomed to the situation in an organization, to be able to fit in properly, perform the assigned task(s) effectively and efficiently, relate hamoniously with other employees and be very productive in such organization. According to Ijeoma and Alutu (2003), orientation can reduce problems of new teachers and non teachers while according to the information from the Office of Human Resources, Oregon State University (shr.oregonstate.edu), orientation provides new employee with conscise and accurate information, necessary to make the employee comfortable in a job; encourages employee's confidence and helps him/her to adapt faster to the job; contributes to a more effective, productive workforce; improves employee's retention; as well as promotes communication between the supervisor and new employee. A beginning teacher needs to be orientated on the duties to perform in a school, how to relate with subordinates and superiors, how to teach effectively, just to mention a few. Ige (2012) opined that orientation should cover: history and philosophy of school, how to work with senior and junior colleagues in school, how to familiarize with pupils/students, how to overcome stage freight, how to mark class register, how to cope with children of diverse nature including the brilliant, dull and difficult ones, how to plan and deliver lessons with confidence, how to use voice appropriately during teaching, how to set questions, mark scripts, record marks/grades and interpret scores, and how to cope with or handle children with special needs. Orientation is a task for school administrators but well knowledgeable individuals can be contracted for this purpose. It is very important that orientation should be a continuous exercise to enable beginning teacher to acquire the necessary knowledge and skills for the discharge of his/her duties in school.

Mentoring: A beginning teacher needs much time on the job and to be appropriately guided in teaching. Display of inexperience is pervasive among teachers, particularly, the beginning teachers. Assigning a beginning teacher to an experienced teacher (i.e. mentor) can help to improve teaching effectiveness of such teacher (Lieberhan, 2011; Mc Dermutt, 2011). It is hopeful that if this is adopted, it will enhance the quality of beginning teacher, improve the academic performance of the pupils/students, as well as improve the standard of education in schools. Research (Strong, Fletcher, \& Villars, 2004) has shown that new teacher who received intensive mentoring had significant effect on his/her students' achievement after as little as two years. According to Joyce and Calhoun (2010), an experienced teacher who acts as mentor to a beginning teacher can perform the following: -.companionship, i.e. discussing ideas, problems, and successes;

-technical feedback, i.e. especially related to lesson planning and classroom observations analysis of application, i.e. integrating what happens or what works as part of the beginning teacher's repertoire

-adaptation, i.e. helping the beginning teacher adapt to particular situation; and -personal facilitation, i.e. helping the teacher feel good about self after trying new strategies

Barkley (2010) and Wright (2010) also stressed that the main features of a successful mentoring program are: proximity, grade equivalence (at the elementary level), subject equivalence (at the secondary level), compatibility (in terms of personality, experiences and educational philosophy). Lunenburg (2011), contends that any good program for helping novice teachers should involve the novice teachers observing the experience teacher on a regular basis and for the experienced teacher to observe the novice teachers. Frey (2011), added that there is need to discuss what facilitated or hindered the teaching-learning process and precisely, what steps or recommendations are needed for improved instruction.

Exposing them to Seminars, Conferences and Workshops: Knowledge acquired by a teacher in institution(s) of learning, are in most cases insufficient for modern day teaching (Adekola, 2007; Adelabu, 2005; Tahir \& Girei, 2009; Thomas, 2011; Umar, 2006). Teaching has indeed grown from the situation it was in the past. Most of the knowledge acquired in institutions, are becoming obsolete and irrelevant to the present situation (Allsop \& Howard, 2009; Thomas, 2011; Umar, 2006). The curriculum of education also keeps changing thus necessitating the updating of the knowledge of teachers from time to time (Allsop \& Howard, 2009; Umar, 2006). It is also imperative for a teacher to go beyond textbooks and attend workshops, conferences, and seminars, to learn new things most of which cannot be seen in such textbooks. Allowing beginning teachers to attend conferences, seminars 
and workshops outside school, can also serve as avenues to acquire new and current knowledge in their subject areas. Specifically, conferences can be general or specific in nature. General conferences are organized for teachers with a view to developing them in the act of teaching. Specific conferences are organized on specific subjects, such as Biology, Chemistry, Physics, English Language, Mathematics, and others. Conferences could be organized by the Ministry of Education or paralstaltas, or by Executives of various subjects Associations. A teacher has to prepare a paper for presentation at conference although he/she may chose to attend the conference without paper presentation. Participants in a conference have the ability to gain experience through papers presented during the conference. A beginning teacher is thus bound to be exposed to much knowledge which he/she may not gather in textbooks or journals. At the end, participants are given certificates of participation or attendance. Education workshop serves as a forum for experts in various aspects of education to train teachers (i.e. participants). Such forum could also enable teacher to enrich his/her knowledge for teaching effectiveness. This can be organized by Ministry of Education, or other Agencies/parastaltals in charge of education supervision and monitoring. Resource persons or facilitators who are experts in the field of education, have to be contracted to handle aspects of the topic. Participants are bound to ask questions on any aspect they are not clear with, which if answered, may go a long way to improve them. Payment of registration and course fees is however sine qua non to the participation of any teacher in a workshop, conference or seminar. Where the fee is minimal or negligible, school administrators can pay for beginning teachers but where it is heavy for the school to bear, recommendation can be made to government on the need to train such teachers. It is germane that when Ministry of Education and other agencies in charge of education organize workshop, conference or seminar, emphasis should be on the beginning teachers, rather than the old teachers. Those selected as trainers should also be knowledgeable than the beginning teachers because it makes no meaning if teachers will not gain new ideas from training as a result of incompetency of trainers. There is even a saying that 'you cannot give out what you do not possess'. It is also important that training should be provided for the teachers on areas where the teacher has little or no knowledge of.

Organising Micro Teaching for Beginning Teachers: Otsupius (2014) asserted that teaching does not merely involve simple transfer of knowledge from one person to another but could be seen as a complex process that facilitates and influences learning. A major weakness noticeable in beginning teachers is that many feel shy to teach, particularly in a large class. It will take some time for a beginning teacher to acquire the trait of boldness and skill of teaching confidently in class. Schools administrators can organize micro-teaching for such beginning teachers. According to Wikipedia, micro-teaching is a teacher training and faculty development technique whereby the teacher reviews a recording of a teaching session, in order to get constructive feedback from peers and/or students about what has worked and what improvements can be made to their teaching technique. According to Ambili (2013), micro-teaching can be practiced with small lesson or a single concept and less number of students. It is an excellent way to build up skills and confidence, to experience a range of lecturing/tutoring styles and to learn and practice giving constructive feedback. Micro-teaching also gives instructors an opportunity to safely put themselves under the microscope of a small group audience but also to observe and comment on other people's performances while it also increases the self-confidence, improves the in-class teaching performances and develops the classroom management skills (Otsupius, 2014).

Regular Supervision and Monitoring: The role of supervision and monitoring in the achievement of organisations' objectives, schools inclusive, cannot be overemphasized. A study of the perceived influence of supervision of instruction on teachers' classroom performance, in Ijebu North Education Zone of Ogun State, Nigeria, by Olawole (2009) revealed that interaction between teachers and instructional supervisors, influences to a great extent, teachers' classroom performance while the use of instructional materials suggested by instructional supervisors influences to a great extent teachers' classroom performance. A beginning teacher needs to be adequately supervised and monitored both in teaching and the discharge of other assigned duties in school. Such supervision and monitoring can be achieved through the schools administrators. Schools administrators should supervise and monitor the daily teaching of the beginning teachers, their records keeping and management, as well as other International Journal of Educational
Studies
Vol. 2, No.4, pp. $261-268$
2019
DOI: $10.53935 / 2641-533 x . v 2 i 4.129$
Funding: This study received no specific
financial support.
Article History:
Received: 16 August 2019
Revised: 26 September 2019
Accepted: 20 November 2019
Published: 19 December 2019
C) 2019 by the authors; licensee Academic
Publishing Group 


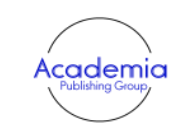

International Journal of Educational Studies

Vol. 2, No.4, pp. 261-268

2019

DOI: $10.53935 / 2641-533 x . v 2 i 4.129$

Funding: This study received no specific

financial support.

Article History:

Received: 16 August 2019

Revised: 26 September 2019

Accepted: 20 November 2019

Published: 19 December 2019

(C) 2019 by the authors; licensee Academic Publishing Group activities in school. Corrections should however be made where necessary so that the mistakes will not be repeated in future.

Exposing them to In-House Workshop/Training: Head of school has major role to play towards achieving effective teaching by teachers and ultimately, improved academic performance of pupils/students and standard of education in the school. Schools administrators can organize internal workshop for the beginning teachers. The Head of Departments, Vice-Principals and even the Principal can serve as trainers in various aspects of teaching, with the aim of improving the teaching effectiveness of the beginning teachers and expose them to more knowledge on teaching aside those gained during training in tertiary institution. Qualified and experienced teachers can also be invited to serve as trainers for teachers.

Provide them Instructional Materials, Textbooks, and other Needs: Instructional materials and text books are very essential for a teacher to teach effectively and achieve the objectives of lesson. According to Okere, Amadi, and R. (2016), no one can adequately talk about qualitative education without reference to the use of qualitative textbooks and other materials. Schools administrators should therefore make it a duty to purchase appropriate textbooks and instructional materials for the use of the beginning teachers so as to achieve effective teaching in their various subjects.

Setting Target for them: School administrators can set target for beginning teachers and allow them to work towards the achievement of these. At the end of the term or session, the performance of such beginning teachers vis- a-vis the target set, has to be examined and assessed. If there is variance, this has to be noticed and discussed with the teacher, with a view to correcting the aspects that caused variance in the future. An online information stated that.

- target setting should be based on qualitative and quantitative evidence about what is working well and what needs attention

- effective targets should be realistic and challenging. Targets that are too difficult and therefore unrealistic can discourage rather than motivate and those that are too easy can lead to complacency.

- Targets should not be imposed on those who have to work with them but rather negotiated and agreed.

- Targets or goals should be SMART - that is, specific, measurable, achievable, relevant and time bound.

- Performance against targets should be monitored on a regular basis to check progress. It is important that targets are taken seriously, but it needs to be a positive process. Failure to meet targeted performance can be used to prompt learning and problem solving to improve performance.

- If targets are not met, there is still an opportunity to focus on what has been achieved, to make a rich assessment of that and share the learning where possible. (http://assessment.tki.org.nz/Using-evidence-for- learning/Target-setting)

- Processes should be established to monitor against targets. For example, an expectation could be:

- weekly monitoring in the classroom, using anecdotal notes, classroom observations and teacher/student conversations

- monthly reporting to syndicate leader or head of department

- term by term reporting to Board of Trustees.

These monitoring processes will be supported by the school-wide assessment schedule

Regular Counseling: Counseling could be a very good motivator of a teacher in school if effectively carried out. A beginning teacher needs to be appropriately counseled, particularly on issues bordering on teaching, relationship with other teachers and school administrators. This role can be performed by school counselor and head including the Head of Departments. New teachers can be invited to the office and advised/counseled on weaknesses noticed in them and other issues that can go a long way to improve their effectiveness in teaching.

Receiving Regular Feedback from Pupils/Students: According to Rutherford Learning Group (www.rutherforlg.com), feedback is essential for improvement of teaching. Johnson (2009), also contended that in order to create a high-performance learning team in classrooms, students and teacher 
have to be accountable to one another. Pupils/students however have important role to play in achieving improved academic standard in a school. They can be helpful in improving the quality of teaching of teachers. Apart from the normal class lesson Attendance Register being given to captain of each class to mark daily, to ascertain the regularity of teachers in class, with a view to determining those that have been absenting themselves from lessons, school head can invite representatives of a class, including the captain to the office for interaction on how beginning teachers are fairing with regards to teaching of the assigned subjects and the weaknesses noticed in them. Also, appropriate proforma can be designed and given to the class captains for assessment of beginning teachers in the course of teaching in classes. At the end of the week, such proforma should be retrieved and assessed by schools' administrators to enable them detect the weaknesses in their teaching. Such weaknesses can be revealed to the teachers with suggestions on how to improve on them.

Exposing them to Group Discussion: It is a common saying that problem shared is half solved. Two heads are also widely believed to be better than one. What this assertion means is that when two individuals relate together and reason on a problem, it will be better than when an individual is involved. School administrators should organize forums for beginning teachers to interact with other teachers, particularly in the same department, where each teacher can discuss his/her problems or challenges in teaching. These can be discussed by such teachers where divergent and different opinions can come out which can really develop such new teachers.

Allocation of Minimum Workload: Workload serve as the number of lesson a teacher will teach in the school per week. It is a fact that in most schools, there is the belief that beginning teachers are fresh in the school and thus have the energy to work and carry out extra duties. Such teachers are often saddled with too much workload. Too much workload however creates stress for teacher more so that such teachers will perform extra curricula activities/ in school. Although increased workload on its own is not necessarily a problem, it is associated with increased stress, burnout and low job satisfaction (Leithwood, Menzies, Jantzi, \& Leithwood, 1996; Wisniewski \& Gargiulo, 1997; Wylie, 1997). The role of schools' administrators is to allocate minimal workload to beginning teachers so as not to be saddled with too much work such that can frustrate them out of teaching. It will also give room for proper attention to pupils/students.

Regular Evaluation: Evaluation can provide a mean through which the status of an employee in an organization can be detected. In a school, evaluation can provide teacher with regular feedback that can help him/her grow as professional. School administrators should thus make it a duty by evaluating the teaching of beginning teachers, with a view to ascertaining the strengths, weaknesses, and providing information to them on how to improve. According to the Teacher evaluation (2010), any teacher evaluation system must meat six standards, in order to be considered effective. They are:

-. all teachers should be evaluated at least annually;

- evaluations should be based on clear standards of instructional excellence that priortise student learning;

- evaluations should consider multiple measures of performance, primarily, the teacher's impact of student academic growth;

- evaluations should employ four to five rating levels to describe differences in teacher effectiveness;

- evaluations should encourage frequent observations and constructive critical feedback;

- evaluations outcomes must matter, evaluation data must be a major factor in key employment decisions about teachers.

International Journal of Educational Studies

Vol. 2, No.4, pp. 261-268

2019

DOI: $10.53935 / 2641-533 x . v 2 i 4.129$

Funding: This study received no specific

financial support.

Article History:

Received: 16 August 2019

Revised: 26 September 2019

Accepted: 20 November 2019

Published: 19 December 2019

(C) 2019 by the authors; licensee Academic

Publishing Group

| 266
Inviting them for Regular Meetings: According to Wikipedia, meeting is a gathering of two or more people, for the purpose of achieving common goal, through verbal interaction, such as sharing information or reaching agreement. The role of meeting in an organization cannot be overemphasized. Specifically, meeting serves as an avenue/forum for interaction of workers in an organization with the management. Also, important information that can contribute to the development of an organization, are revealed during meeting. It is also stated online (www.meetingking.com) that meetings, if done properly, are the most effective way of making decisions and motivating staff. Schools administrators should thus create opportunity for regular meeting with beginning teachers, so as to ascertain their complaints, needs, impression on the situation in school, as well as make them feel more engaged in 
school. It is very important that such meeting should be attended by Head of Departments who are directly in charge of supervision and monitoring of the beginning teachers.

\section{Summary and Conclusion}

The role of teachers in a school setting cannot be overemphasized. Teachers are the major 'dramatis personae' in school, apart from the pupils/students. Effectiveness of a beginning teacher has been a problem for schools' administrators because of their inexperience in teaching and the implications of allowing them to teach without proper attention. In this paper, various ways through which a beginning teacher can be assisted to achieve effective teaching in school were discussed. In view of the enviable role of teacher in school and the negative effect of teaching by beginning teachers in school, it is imperative for schools' administrators to devise means such as those suggested above, to ensure that the beginning teachers key into the objectives of school and improve on their effectiveness in teaching. With this fully achieved, good quality education in school will be a reality.

\section{References}

Abdurrahman, K. (2016). Problems of novice teachers: Challenges versus support. Journal of Education in Black Sea Region, 1(2), 92101.Available at: https://doi.org/10.31578/jebs.v1i2.22.

Achistein, B., \& Barret, A. (2004). Refraining classroom contexts: How new teachers and mentors view diverse learners and challenges of practice. Teachers College Record, 106(4), 716-746.

Adekola, O. A. (2007). Language, literacy and learning in primary schools: Implications for teacher development programs in nigeria. World bank working paper. Washington DC: Africa Region Human Development Department, World Bank.

Adelabu, M. A. (2005). Teacher motivations and incentives in nigeria. Unpublished country case study report for p. Bennell and $k$. Akyeampong (2007) teacher motivation in sub-saharan africa and south asia. Researching the issues report no. London: DFID.

Afe, J. O. (2003). Teacher effectiveness: Imperative for implementing universal basic education in Nigeria. Journal of Nigeria Academy of Education, 1(1), 1-9.

Aitken, R., \& Harford, J. (2011). Induction needs of a group of teachers at different career stages in a school in the republic of ireland: Challenges and expectations. Teaching and Teacher Education, 27(2), 350-356.

Akpan, A. A. (1996). Teacher effectiveness as a determinant of student' performance in Mathematics: A theoretical review. Journal of Research Information in Education, 1(1), 89-99.

Allsop, T., \& Howard, L. (2009). An assessment of teacher education in Jigawa State. ESSPIN Report No. JG301. ESSPIN: Abuja.

Ambili, R. (2013). Microteaching: An efficient technique for learning effective teaching. Journal of Research in Medical Sciences, $18(2), 158-163$

Barkley, S. G. (2010). Quality teaching in a culture of coaching. Rowman and Littlefield. Maryland, USA: Lanham.

Cantu Tijerina, M. Y., \& Martinez Sanchez, N. H. (2006). Problems faced by beginning teachers in private secondary schools: A comparative study between Spain and Mexico. Revista Electronic de Investigacion Educative, 8(2), 1-16.

Evans, E. D. (2006). Transition to teaching. New York: Holt, Rinehart and Winston.

Frey, N. (2011). The formative assessment action plan: Practical steps to more successful teaching and learning. Association for Supervision and Curriculum development. USA: Virginia.

Fry, S. W. (2007). First-year teachers and induction support. Ups, downs, and in-between Qualitative Report, 12(2), $216-237$.

Goddard, R., \& Goddard, M. (2006). Beginning teacher burnout in queens land schools: Associations with serious intentions to leave. Australian Educational Researcher, 33(2), 61-75.

Harris, K., Jenz, F., \& Baldwin, G. (2005). Who's teaching science?: Meeting the demand for qualified science teachers in Australian secondary schools. In Report for Austalian Council of Deans of Sciences, Melbourne Australia: Centre for Study of Higher Education, University of Melbourne.

Hover, S. D., \& Yeager, E. A. (2004). Challenges facing beginning history teachers: An exploratory study. International Journal of Social Education, 19(1), 8-26.

Ige, A. (2012). In-School teacher's development strategies for effective teaching of subjects in the new universal basic education curriculum in Nigeria. Journal of Educational Research and Development, 6(3), 1-8.

Ijeoma, M. F., \& Alutu, A. N. G. (2003). Administrative tools for enhancing teacher/counsellor's productivity. In C.C Nwagwu and A.O Imogie (Eds). Educational standards in the 21st century in Nigeria. Benin City, Nigeria: Institute of Education, University of Benin.

International Journal of Educational

Studies

Vol. 2, No.4, pp. 261-268

2019

DOI: $10.53935 / 2641-533 x . v 2 i 4.129$

Funding: This study received no specific

financial support.

Article History:

Received: 16 August 2019

Revised: 26 September 2019

Accepted: 20 November 2019

Published: 19 December 2019

(C) 2019 by the authors; licensee Academic

Publishing Group

Ingersoll, R. M. (2001). Teacher turnover and teacher shortages: An organizational analysis. American Educational Research Journal, 38(3), 499-534.

Johnson, B. (2009). Student feedback help teachers grow. Edutopia: Retrieved from: https://www.edutopia.org/student-feedbackaccountability-teachers.

Joyce, B., \& Calhoun, E. (2010). Models of professional development: A celebration of educators. California, USA: Corwin Press.

Leithwood, K., Menzies, T., Jantzi, D., \& Leithwood, J. (1996). School restructuring, transformational leadership and amelioration of teacher burnout', anxiety, stress and coping. An International Journal, 9(3), 199-215.

Lieberhan, A. (2011). Mentoring teachers: Navigating the real-world tensions. New York, USA: Wiley.

Lundeen, C. A. (2004). Teacher development: The struggle of beginning teachers in creating Moral caring classroom environments. Early Childhood Development and Care, 176(6), 549-564. 

Supervision Journal, 28(4), 1-5.

Matthews, J. (2011). New teacher decries lesson plan gap. Retrieved from: www.washingtonpost.com.

Mc Dermutt, L. (2011). Enhancing practice through classroom research; A teacher's guide to professional development. Ney York, USA: Routhledge.

Melnick, S., \& Meister, D. (2008). A comparison of beginning and experienced teachers' concerns. Educational Research Quarterly, 31(3), 39-56.

National Centre for Education Statistics. (2010). The condition of education. Washignton, DC, USA: Government Printing Office.

O'Brien, P., \& Goddard, R. (2006). Beginning teachers: Easing the transition to the classroom. Australian Educational Leader, 28(1), 28-31.

Okere, L., Amadi, O., \& R., A. (2016). Textbook crisis and the challenges for sustainable educational quality in Nigeria. International Journal of Innovative Education research, 4(2), 40-45.

Olawole, O. O. (2009). Perceived influence of supervision of instruction on teachers' classroom performance in ijebu-north education zone of ogun state. Nsukka: Unpublished M.Ed Project, University of Nigeria.

Otsupius, I. A. (2014). Micro-teaching: A technique for effective teaching. African Research Review, 8(4), $183-197$.

Rhodes, C. P., Nevill, A., \& Allan, J. (2004). Valuing and supporting teachers: A survey of teacher satisfaction, dissatisfaction, morale, and retention in an English local education authority. Research in Education, 71, 67-80.

Robinstein, G. (2010). Beyond survival: How to thrive in middle and high school for beginning and improving teachers. New York, USA: Mc-Graw Hill.

Strong, M., Fletcher, S., \& Villars, A. (2004). An investigation of the effects of teacher experience and teacher preparedness on the performance of Latino students in California. California, USA: New Teacher Centre: Santa Cruz.

Tahir, G., \& Girei, S. B. (2009). Teacher preparation and challenges of the universal basic education programme in nigeria. In: A. Garuba and l. Irwin (eds.), teaching and education for teaching in developing countries. Accra: Adwinsa Publishers.

Taneri, P. O. (2004). A study on novice classroom teachers' problems with regular and alternative certificates. Unpublished Master's Thesis, Middle East Technical University, Ankara.

Teacher evaluation. (2010). In the new teacher project. Retrieved from: www.tntp.org.

Thomas, H. (2011). Study of teacher management and deployment. ESSPIN Report No. 328. ESSPIN: Abuja.

Umar, A. (2006). The teacher education curriculum and the world of work: A study of teachers of disadvantaged children in Nigeria. Teaching and Teacher Education, 33(7), 777-787.

Veerman, S. (1984). Perceived problems of beginning teachers. Review of Educational Research, 54(2), 143-178.

Vogt, W. (1984). Developing a teaching evaluation system. Spectrum, 2(1), 41-46.

Wisniewski, L., \& Gargiulo, R. M. (1997). Occupational stress and burnout among special educators: A review of the literature. The Journal of Special Education, 31, 325-346.

Wright, T. (2010). How to be a brilliant mentor: Developing of outstanding teachers. New York, USA: Taylor and Francis.

Wylie, C. (1997). In Wellington: New Zealand council for educational research. Self-managing schools seven years on: What have we learnt?

Yalcnkaya, M. (2002). Yeni ogretmen ve teftis. Milli Egitim Dergisi, 150, 153-154.

International Journal of Educational
Studies
Vol. 2, No.4, pp. $261-268$
2019
DOI: $10.53935 / 2641-533 x . v 2 i 4.129$
Funding: This study received no specific
financial support.
Article History:
Received: 16 August 2019
Revised: 26 September 2019
Accepted: 20 November 2019
Published: 19 December 2019
C 2019 by the authors; licensee Academic
Publishing Group 